\title{
Negation in Ancient Greek: \\ a Typological Approach*
}

\author{
Dagmar Muchnová
}

(Charles University in Prague)

\begin{abstract}
This article deals with the application of the concept of negative concord (Giannakidou, Horrocks, Denizot, Willmott), which is not reflected in standard reference books on Ancient Greek (including the most recent books by Basile and Crespo) and is not used in Czech Hellenistic circles. Taking into account the well-known rule of the accumulation of negatives of the same kind ( $o \dot{v}$... o ov $\delta \varepsilon i \zeta, o \dot{v} \delta \varepsilon i \zeta \ldots o v$ ), the author offers support for certain surprising yet convincing

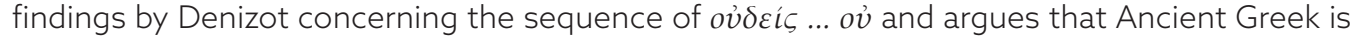
a non-strict negative concord language.
\end{abstract}

\section{Keywords}

negation in Ancient Greek; n-words; negator; negative concord; negative spread; non-strict negative concord language

\section{Introduction}

All Czech classical philologists are familiar with the chapter in Niederle's Mluvnice reckého jazyka (Greek Language Grammar, 1974: p. 274), dealing with the so-called accumulation of negatives, entailing two basic rules, namely, that "negatives are rendered invalid when the last one is simple," and "negatives are reinforced when the last one is compound". ${ }^{1}$ However, not much attention has been paid to the extent to which these definitions which are given in practically all Greek grammars are actually valid. The question is whether this 'peculiarity' is only found in Greek or whether it also holds true for other languages. The aim of this article, therefore, is to examine the two above-mentioned rules in the light of current linguistic concepts of negation, and to contribute to what is

* This study was written within the Programme for the Development of Fields of Study at Charles University, No. P10, Linguistics, sub-programme Comparative Linguistics. My grateful thanks to anonymous reviewers who saved me from myself on numerous occasions and offered valuable suggestions for improvement of this article.

1 Similar treatment can be found in Bornemann \& Risch (1978: pp. 260-261) and other school grammars. 
known about the character of Ancient Greek negation, a subject on which scholars have so far failed to reach accord.

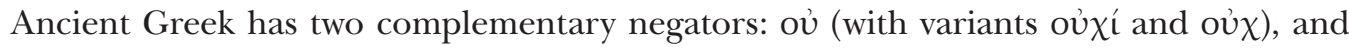
$\mu \eta$, the former of which is mainly used in assertive statements ('objective/epistemic negation'), and the latter in orders and wishes ('subjective/deontic negation'). ${ }^{2}$ This distribution reflects the Proto-Indo-European dichotomy which also applies in Latin (non vs $n e$ ). The distributional difference between ov and $\mu \eta$ also holds true for their com-

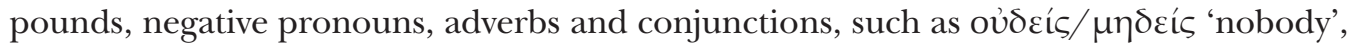

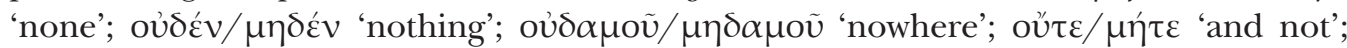
oủ $\delta \dot{\varepsilon} / \mu \eta \dot{\delta} \delta$ 'and not, not even', etc. This type of dichotomy occurs only rarely in any of the known modern European languages: it does, for instance, in the Modern Greek contrast of $\delta \varepsilon(v)$ vs $\mu \eta(v) .^{3}$

The two Ancient Greek negators (ov̉ and $\mu$ í), which function as markers of sentence

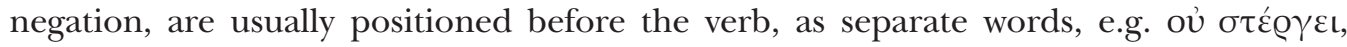

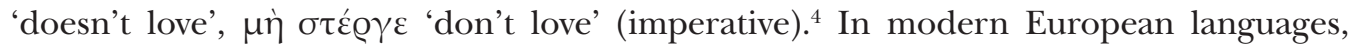
sentence negation is expressed by various means: by the use of a specific word, such as nicht, which - unlike in Ancient Greek - is placed postverbally (in German: er arbeitet nicht); by the use of an auxiliary verb, such as does not/do not (in English: he does not work); by means of a bipartite negator, such as ne ... pas, whose the first and the second part are

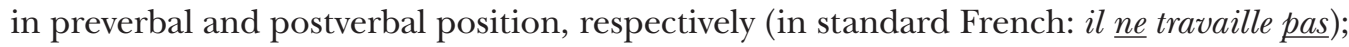
or by the use of the morpheme ne-, usually functioning as a bound morpheme, chiefly as a verbal prefix (in Czech: nepracuje).

Unlike in some other languages, in Ancient Greek a single sentence may contain two or more negative morphemes (cf. also Muchnová 2014). This comprises the cases of:

(a) co-occurrence of negators of different kinds, i.e. association of ov่ $+\mu \eta$ and $\mu$ í + ovं; (b) co-occurrence of identical-kind negators, either 'objective' (oủ oủ $\delta \varepsilon i ́$ 'no one'; oủ

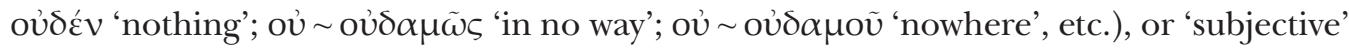
( $\mu \eta \dot{~} \sim \mu \eta \delta \varepsilon i \varsigma, \mu \eta \delta \varepsilon ́ v, \mu \eta \delta \alpha \mu \delta \tilde{v}, \mu \eta \delta \alpha \mu \tilde{\omega} \varsigma$, etc.).

In authoritative Ancient Greek grammars, both instances are treated either together, under the heading of Häufung der Negationen (Kühner \& Gerth 1904: pp. 203-223, esp. 204-205; Schwyzer \& Debrunner 1966: pp. 597-598), négations combinées (Humbert 1972: pp. 363-367), or separately (Smyth 1984: pp. 622-628 and 628-629). Smyth reserves the term accumulation of negatives exclusively for the second phenomenon. The

2 For more detailed description of the differences of use of oủ and $\mu \eta$, see e.g. Willmott 2013.

3 Modern Greek $\delta \varepsilon(v)<$ Ancient Greek oủঠćv, while Modern Greek $\mu \eta(v)[\mathrm{mi}]<$ Ancient Greek $\mu \eta ́$.

4 The negator, though, may also be positioned elsewhere in a sentence, notably so in poetry, even at the very end of a sentence, for instance as a marker of emphasis or contrast, in which case however it is ac-

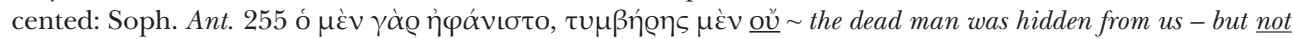
buried. 
present article will focus on the co-occurrence of a negator and a negative pronoun or adverb (or some other compound negative) of the same kind (cf. (b) above), with the morpheme où:

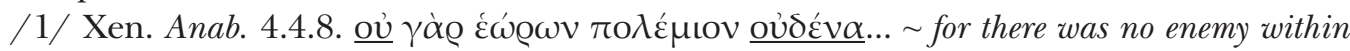
sight. ${ }^{5}$

\section{Negative concord, n-words, and NPIs}

The co-occurrence of a negator and another negative word is typical for negative concord languages including notably Czech and other Slavonic languages. Negative concord has been defined by Horrocks (2014: p. 48) as "the use of more than one negative item in a construction that carries only a single negative reading." Similarly Willmott (2013: p. 329) notes that "negative concord may be briefly described as follows: in sentences with two (or more) apparently negative elements (normally a negator and one or more so-called n-words), they do not 'cancel out' the negative meaning (as they do in English), but rather, the sentence has a negative meaning." Applying this definition to Czech, ${ }^{6}$ we can say that in the case of "global" negation, ${ }^{7}$ a single sentence can contain, apart from a negator (sentential negation), also one or more so-called n-words (negative words), but as a whole the sentence retains its negative meaning:

\section{/2/ Nikdo nikdy neprǐšel.}

n-word n-word NEG verb

Nobody ever came.

Here, the Czech sentence contains three negative elements (two n-words, plus the negator $n e-$ ), and the presence of the negator is obligatory (one cannot say $\underline{n i k d o ~ p r i s ̌ e l) . ~ T h i s ~}$ leads to an intuitive impression of a 'concord' between n-words and negator (within the negative statement), where the n-words do not assign their own negative meaning to the sentence. Logically, indeed, two negations would be supposed to produce affirmation.

The term n-words denotes a negated form of indefinite pronouns, adjectives and adverbs (Cz. něco 'something' Cz. nic 'nothing'), though their nature continues to be subject to scholarly debate. According to Denizot (2012: p. 65, n. 3), n-words in Ancient Greek

5 The translations are mostly borrowed from Loeb edition, with slight modifications, if needed.

6 The comparison with Czech is intentional because both languages, Czech and Ancient Greek, are negative concord languages.

7 Mluvnice čěstiny III (1987: p. 264) stipulates that "global" negation "is expressed by sentences with a sentence negation and a so-called negative concord in which the negative form is assigned also to pronominal, adverbial and adjectival full-scale quantifiers, i.e. expressions with a universal quantifier (e.g. všude $>$ nikde ['everywhere' > 'nowhere', $\mathrm{DM}]$ ), as well as indefinite identifiers, i.e. expressions with a partial (existential, DM) quantifier (e.g. někteřri/někdo > nikdo ['somebody' > 'nobody', DM])." Cf. also Kosta (2001: p. 121). The authoritative Czech monographs on negation (Hajičová 1975, and Dočekal 2015) do not deal with negation from a typological perspective. 
can be interpreted as negative quantifiers; according to Willmott (2013: p. 329), n-words in Ancient Greek "appear to be inherently negative, being made up of the negator in compound with another element"; according to Horrocks (2014: p. 80), negative indef-

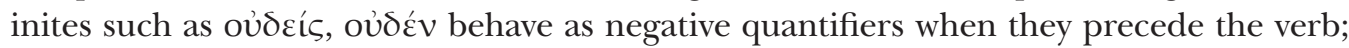
when they follow the verb with oú, they behave as so-called NPIs. On the whole, however, it becomes evident that the nature of n-words varies from language to language. Arguments have recently multiplied against their (inherently) negative nature in languages where one might be intuitively tempted to agree with it (cf. Cz. nikdo 'nobody'; Cz. nic 'nothing'). ${ }^{8}$ Nevertheless, as this problem is of no crucial relevance to the topic of the present article, this issue will be disregarded here.

Unlike Czech, standard English does not permit the parallel use of negator and negative pronoun in a single sentence when the whole sentence is supposed to express a negative meaning: thus one cannot say * "I didn't say it to nobody." A sentence like "I didn't say it to nobody" can only have a positive reading, that is, it is a sentence with double negation, ${ }^{9}$ meaning "I said it to somebody." The corresponding negative sentence would then be "I didn't say it to anybody", that is, it would include an indefinite pronoun or, more precisely, a so-called NPI. Languages without negative concord like English ${ }^{10}$ use in negative contexts (in combination with a negative operator) so-called negative polarity items (NPIs, e.g. 'anybody'), and in positive contexts (affirmative sentences), so-called PPIs (positive polarity items, e.g. 'someone'), as in "I said it to someone."

Negative contexts are considered as anti-veridical, as opposed to positive statements which are veridical. Beyond that, there also exist various affective contexts, such as questions, modal expressions, imperative and conditional clauses ${ }^{11}$ and the like, which in their turn are non-veridical; their semantic function does not secure the veracity of a statement. These so-called APIs (affective polarity items) make possible the choice between PPIs and NPIs. ${ }^{12}$

\section{Niederle's definitions}

Ancient Greek - like Czech - allows two and more negative items of the same kind (oú

8 Cf. e.g. Dočekal (2007), Giannakidou (2006), Horrocks (2014, with a fine analyse of the functioning Greek negative indefinites), all of whom dispute the inherently negative character of n-words.

9 In earlier scholarly literature and in non-specialized circles, this term is occasionally used to denote a case of what is today known as negative concord. The present-day term double negation relates to the semanticlogic language level: two or more negative expressions in a sentence eliminate each other, making such a sentence equivalent to an affirmative sentence as regards truth conditions (albeit not so as regards its pragmatic context) (cf. Willis et al. 2013: p. 30).

10 Cf. e.g. Dočekal (2007: p. 5).

11 E.g. "If someone says/If anyone says..."

12 Horrocks (2014: pp. 47-48); Giannakidou (2006, 2011). 
or $\mu \eta$ series; negator and n-word) in a same clause; this phenomenon is referred to in grammar textbooks as a case of accumulation of negatives (Niederle et al. 1974: p. 274):

(a) if the last negation in a clause is a compound negation, ${ }^{13}$ such as oúdév, $\mu \eta \delta \varepsilon \dot{v}$ 'nothing', the negations reinforce each other, i.e. the meaning of the sentence as a whole is negative, as in the following cases:

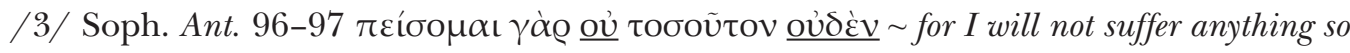
terrible

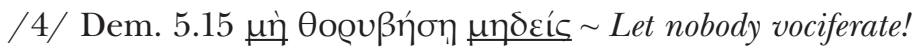

Using modern terminology, this rule would read: if in the same clause a negator precedes an $n$-word, the resulting interpretation is negative. This phenomenon is known as negative concord: the sentence is interpreted as having only one semantico-logical negation (similarly as in $/ 2 /$ in Czech).

(b) if the last negation in a clause is simple negation, i.e. ov่, $\mu \eta$, the negations are cancelled; this results in an affirmative reading of the whole sentence, as in:

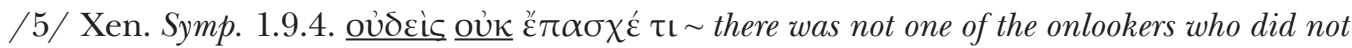
feel ... $\rightarrow$ each onlooker did feel something...

Using modern terminology, this rule would read: if in one sentence an $n$-word precedes a negator, the result is double negation, and the resulting reading is more or less affirmative. In such cases, two (or more) negations are neutralised (Denizot 2012: p. 65).

The rules concerning accumulation of negatives of the same kind can be resumed in two following formulas:

negator + n-word $\rightarrow$ negative concord (negative meaning)

n-word + negator $\rightarrow$ double negation (affirmative meaning)

In practice, not only good grammar textbooks (Rijksbaron et al. 2000: p. 154), but even prestigious scholarly compendiums, ${ }^{14}$ including recent ones, such as Crespo et al. (2003: pp. 224-225), and Basile \& Radici Colace (2001: pp. 110-112), contain rules formulated in a similar way as those drawn up by Niederle.

The phenomenon may be accounted for by the fact that an anticipated negator has within its scope ${ }^{15}$ all of the following n-words which it appears to absorb, the whole pattern then in fact amounting to a single semantic-logical negation. If, however, a negator

13 The same terminology is used by Kühner \& Gerth (1904: p. 205): zusammengesetzte and einfache Negation.

14 Cf. section 1.

15 The relevance of negator scope is also duly noted by Horrocks (2014: p. 52). 
follows an n-word, then that n-word is not within the scope of the negator ${ }^{16}$ and each of the negations is interpreted separately; this corresponds to the kind of double negation exemplified in $/ 5 /$.

\section{Non-strict negative concord languages: Italian, Spanish, and Ancient Greek}

Similar patterns of negation also hold true for Italian and Spanish, the only difference is that it is the position (preverbal or postverbal) of the n-word with respect to the verb, which is relevant. ${ }^{17}$ In both languages, the structure neg + verb $+n$-word produces negative concord and negative reading of the whole sentence (cf. /6/ and / $7 /$ below), whereas the sequence of n-word + neg + verb would produce double negation and more or less affirmative reading of the sentence (cf. $/ 8 /$ and $/ 9 /) .{ }^{18}$

/6/ Gianni non ha visto nessuno. ${ }^{19} \sim$ Gianni has seen nobody.

$/ 7 / \underline{\text { No vi nada }} .^{20} \sim$ I saw nothing.

In examples /6/ and /7/ the negator stands in preverbal position and is obligatory, whereas the n-word is postverbal.

/8/ Nessuno non ha visto Gianni. It's not the case that nobody saw Gianni. ( $\rightarrow$ Somebody saw Gianni.) ??

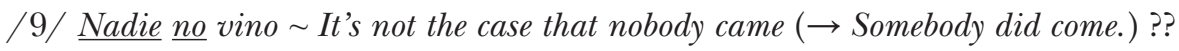

In examples /8/ and /9/ the n-word + negator are placed preverbally; the 'normal' reading would suggest a double negation pattern, with an affirmative reading. However, it should be noted that this is a rather non-prototypical construction, which some scholars even consider to be agrammatical. On the other hand, a construction with a preverbal $\mathrm{n}$-word but without negator is much more common. The meaning of such sentence is negative, as the n-word, nessuno, takes over the function of the negator:

\section{/10/ Nessuno ha visto Gianni. Nobody has seen Gianni.}

In other words, negative reading precludes the use of the sentence negator when the n-

16 Denizot refutes this explanation, cf. (2012: p. 85).

17 This description is common in modern languages.

18 Cf. Denizot (2012: p. 69), with further references to other literature.

19 The Italian examples are taken from Horrocks (2014: p. 49); similar examples are presented by Denizot (2012: p. 68) and others.

20 The Spanish examples are inspired by Haspelmath (2013: chap. 115). 
word precedes the verb; in contrast, when the n-word occurs in postverbal position, the sentence negator is obligatory.

Linguists ${ }^{21}$ classify languages like Italian and Spanish into the category of negative-concord languages. Since, however, the concord does not occur without exceptions, these languages are further subcategorized as featuring non-strict negative concord. On the other hand, languages such as Czech, where the presence of the negator is obligatory in all negative contexts, are subcategorized as strict negative concord languages.

A comparison of the two above-mentioned languages with Ancient Greek shows two important points:

(a) Like Italian and Spanish, Ancient Greek standardly uses constructions with n-word in preverbal position, without a negator:

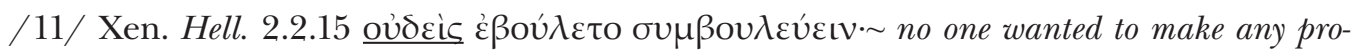
posal

Unlike in the two modern languages, the presence of a negator is not obligatory in Ancient Greek when the n-word occurs after the verb:

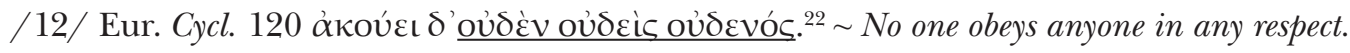

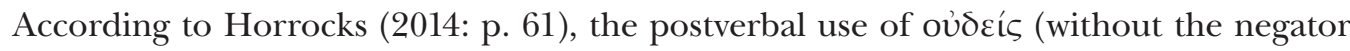
ou) is very rare, and is only found in cases of emphasis, contrast or topicalization, that is, in statements where the word order is not pragmatically neutral. However, the existence of actual instances ${ }^{23}$ suggests that this pattern is possible, even if required by specific communicative aims, and that Horrocks' claim ${ }^{24}$ about the almost obligatory presence of the negative ou should be verified. At the same time, the use of an isolated postverbal n-word is more frequent than the use of the sequence of n-word + negator with the double negation reading (cf. section 5.), which Horrocks - with some reservation - takes into account.

(b) In Italian and Spanish, the (non-standard) variant with the order of n-word + neg (cf. $/ 8 /$ and $/ 9 /$ ) could probably be read as double negation (with affirmative meaning). Both scholarly grammars and Horrocks (2014: p. 44) claim that the same holds true for

21 E.g. Willis et al. (2013: p. 34); Horrocks (2014: p. 52).

22 Example taken over from Denizot (2012: p. 67).

23 Horrocks cites three examples (Thuc. 3.68.2; 1.125.5; and Dem. Epit. 7.4). One may add to these the randomly excerpted cases of Aristot. Eth. Eud.. 1224, and Aeschin. Tim. 95.7-8.

24 Horrocks (2014: p. 44): "When a form of oudeis appears postverbally, ou( $k$ ) is all but obligatorily present, at least with finite verb forms." 


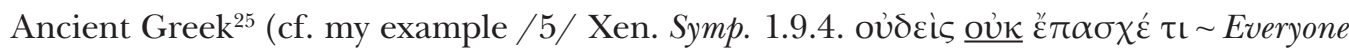
felt something...). However, this alternative was questioned by Denizot (cf. section 5.).

In sum, comparison with Italian and Spanish suggests that Ancient Greek may be regarded as a non-strict negative concord language: apart from the possibility of accumulating a negator and one or more n-words in a single clause, with a negative reading (which is typical of strict negative concord languages), the function of sentence negation can also be assumed by an n-word alone, without a negator, as was shown by examples /11/ and /12/ above. Now it is important to tackle the controversial question of accumulation of negatives in the sequence of n-word + negator.

\section{Sequence of $\mathbf{n}$-word + negator}

As has been shown, in modern languages a crucial parameter in the interpretation of negation is the position of n-words with respect to the predicate (to the finite verb); some scholars tacite apply this parameter also to Ancient Greek (Horrocks 2014, Giannakidou 2006). In contrast, authoritative grammars as well as some modern studies on Ancient Greek (Willmott 2013, Denizot 2012) focus on the relative ordering of neg + n-word; this approach is typologically rather isolated. In the future it will be inevitable to assess both approaches on the grounds of extensive excerption from Greek authors, before deciding about the scholarly relevance of the positioning of n-words in Ancient Greek with respect to predicate verbs. ${ }^{26}$

\subsection{Double negation reading}

The existence of double negation is asserted with assurance in all Ancient Greek grammars; however, this phenomenon is exemplified by only a handful of examples and the same examples are repeated in all grammars. While notes about the sparse occurrence of the sequence of n-word + negator did occasionally already appear in works by some scholars in the past, ${ }^{27}$ it was Denizot (2012: p. 73) who made it clear (basing herself on her own excerption of material) that there exist only ten documentable instances of this sequence. Only four of them can potentially be interpreted as double negation:

- Soph. fr. 935.3. (Radt)

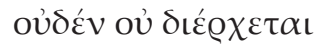

- $\quad$ Dem. 36.46.1.

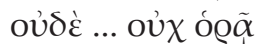

- Hdt. 5.56.5

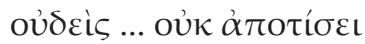

- Xen. Symp. 1.9.4. (cf. ex./5/)

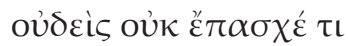

25 Horrocks (2014: p. 60, n. 30) characterizes the occurrence of this construction as sporadic.

26 Denizot (2012: pp. 70-71) argues that for Greek, with its relatively free word order, such restrictions (concerning the relative position of the n-word and negator, or the position of negatives with respect to predicate verbs) appear to be at least unusual.

27 E.g. Kühner \& Gerth (1904: p. 205, Anm. 1). 
When discussing these cases, Denizot observed that the first two are at least questionable.

\section{Sophocles}

The fragment from Sophocles is quoted in various editions with several variae lectiones. The interpretation involving double negation is only mentioned by Kühner \& Gerth (1904: p. 205, Anm. 1, with a note on questionable reading); they adopt the variant

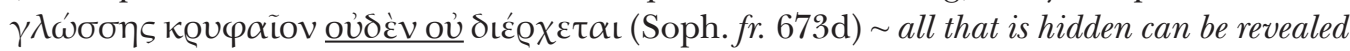
(lit. all that is hidden passes through the tongue). In other text editions, however, oủdeí oủ

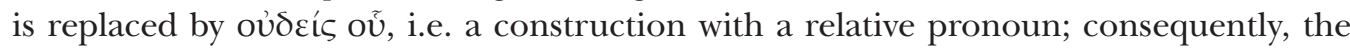
sentence has only one negation, namely, the n-word:

\section{$/ 13 /(\text { Soph. fr. 935) })^{28}$}

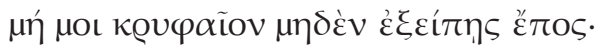

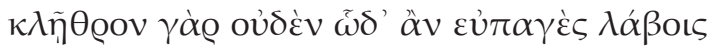

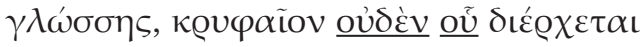

do not tell me any secret; you cannot have any tongue bar strong enough through which will pass no secret. (litt.)

The argumentation of Denizot (2012: pp. 73-74) is convincing enough; this case cannot be taken as a valid argument in favour of double negation.

\section{Demosthenes}

Similarly, the example taken from Demosthenes, where the orator explains why the accused holds no valid claim to Formion's property, is not entirely unambiguous:

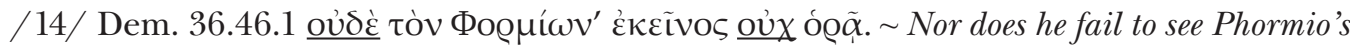
condition. (= standard translation)

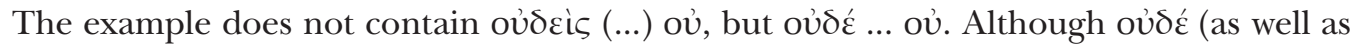
oú $\tau \varepsilon$ ) is neither a pronoun nor an adverb, it is usually classified in the category of compound negative ${ }^{29}$ expressions: oủ $\delta \dot{\varepsilon}<$ oú + particle $\delta \dot{\varepsilon}$, oú $\tau \varepsilon<$ oủ + particle/conjunction $\tau \varepsilon$. The example taken from Demosthenes has been traditionally ${ }^{30}$ read as a case of double negation: Antimachus sees Phormio, that is: Phormio's situation is known to Antimachus. Denizot (2012: pp. 74-76), however, demonstrates that the corresponding translation ought to be: "Phormion non plus, celui-ci ne le voit pas." (p. 75), that is: neither does Antimachus know Phormio's situation (i.e. with negative concord). In her interpretation, the particle oủঠé functions as the focusing negation 'neither', rather than as the negative

28 Radt (1977).

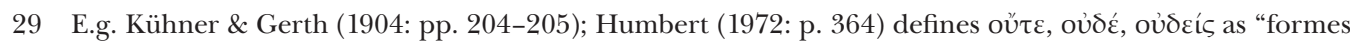
composées".

30 Kühner \& Gerth (1904: p. 205, Anm. 1); similarly also L. Guernet in the Collection Budé edition, and A. T. Murray in Loeb's edition (cf. Denizot 2012: p. 74). 
conjunction 'and not'. Her interpretation is plausible; actually, in some manuscripts oủ $\chi$ is omitted. Additionally, there is another element in support of Denizot's argument: the construction oủঠé ... oủ is in many other cases interpreted in terms of negative concord (Kühner \& Gerth 1904: pp. 204-205, Anm. 1). ${ }^{31}$

\section{Herodotus}

Another example is taken from Herodotus: it occurs in a couplet in the dactylic hexameter uttered by the apparition in the dream of Hipparchus:

\section{/15/ Hdt. 5.56.5

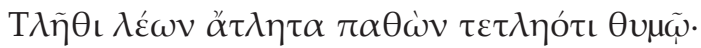

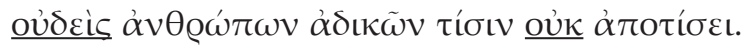 \\ "O lion, endure the unendurable with a lion's heart. No man on earth does wrong with- out paying the penalty." (Read: every trespasser will be punished.)}

This verse can only be interpreted as an instance of double negation; however, there are certain peculiarities which Denizot (2012: pp. 76-79) convincingly elucidates with references to secondary literature. These mainly concern the ambiguity of prophecies in Herodotus:

(a) the root tla- 'take', which occurs three times in the first line, has two meanings: to withstand, and to be accountable. Therefore, the text offers two context-bound readings: either the apparition invites Hipparchus to be brave, in which case Hipparchus is the victim (who will be avenged), or the apparition invites him to assume responsibility for his deeds, in which case he can be punished. According to the interpretation of the verb, the message is either one of encouragement in facing up to fate, or one of warning.

(b) another ambiguity consists in that it is not evident whether the addressee of the apparition is Hipparchus himself, or whether the statement merely conveys a generally established fact. Hipparchus obviously does not understand this message as a warning and he participates in a procession (during which he perishes). This referential opacity

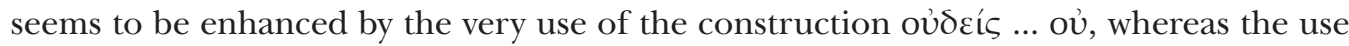

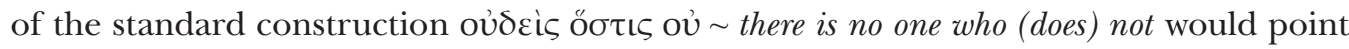
to double negation (positive meaning) in a unambiguous way.

\section{Xenophon}

Similarly the last example, taken from Xenophon, can be interpreted solely in terms of double negation:

$/ 16 /=/ 5 /$ Xen. Symp. 1.9.4. [The eyes of all the onlookers were attracted to Autolycus'

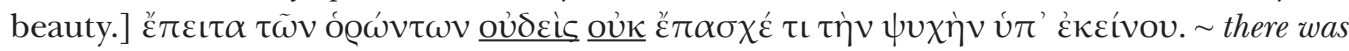
not one of the onlookers who did not feel his soul strangely stirred by the boy; i.e. everyone felt something.

31 Denizot herself adds two examples from Herodotus (1.84.10 and 4.28.17), cf. examples /21/ and /22/ here. 
Denizot (2012: p. 81) points out that "l'indéfini révèle une présupposition positive de l'existence d'un procès", even though the pronoun co-occurs with negation. Actually, interpretation in terms of double negation implies reversal of polarity; the outcome is an affirmative context in which the indefinite pronoun $\tau \iota$ can be used referentially. In contrast, in the construction commonly employed to express double negation, namely,

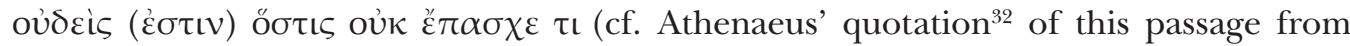
Xenophon), the referential (épistémique) function of $\tau \iota$ (= 'something') cannot be taken for granted, according to Denizot (2012: pp. 80-82).

\subsection{Counterexamples}

\section{The sequence oủ $\delta$ ís (...) oủ}

As has already been noted above, cases with the sequence of n-word + neg are extremely rare, in all amounting to no more than ten. Apart from four cases involving double negation, of which two were questioned - as indicated above - by Denizot, the remaining cases exclude double negation reading, due to the context.

Of the six cases with the sequence of n-word + negator, four contain the pronoun oúdeís (nom. sg. n. as subject; nom. sg. masc. as subject, and dat. sg. masc. possessor). In three of them, the negative ou negates coordinate, asyndetically linked nouns:

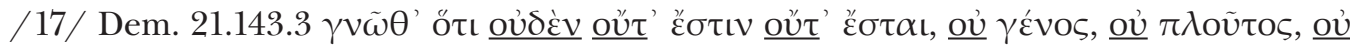

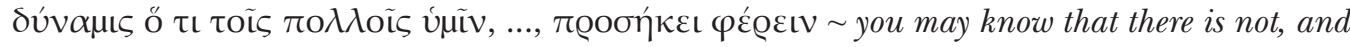
never will be, anything - not birth, not wealth, not power - that you, the great mass of citizens, ought to tolerate.

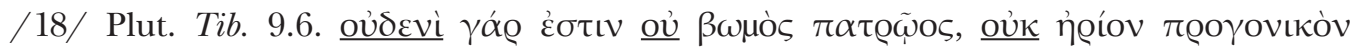

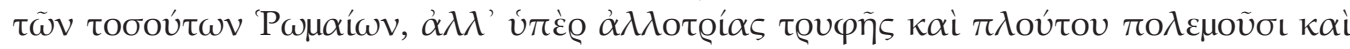
$\dot{\alpha} \pi \mathrm{\theta} \theta \dot{\gamma} \sigma \kappa \mathrm{\sigma} \sigma \mathrm{\iota} \sim$ for not a man of them has an hereditary altar, not one of all these many Romans an ancestral tomb, but they fight and die to support others in wealth and luxury.

/19/ Aristoph. Pl.1114

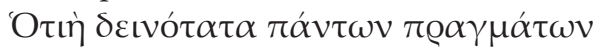

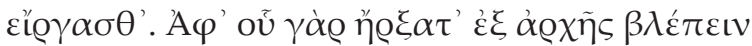

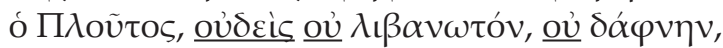

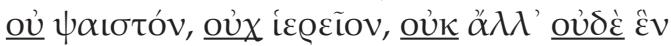

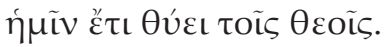

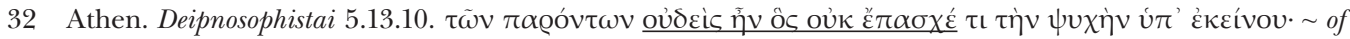
those present there was no one who would not have experienced something in their soul under his influence, i.e. everyone had experienced something... Apart from the different ways of expressing double negation, the two texts also differ in the use of participles: Athenaeus has $\tau \alpha \varrho o ́ v \tau \omega \nu$, Xenophon ó@ $\omega \nu \tau \omega \nu$. 
$\sim$ Because you have committed the most dreadful crime. Since Plutus has recovered his sight, there is nothing for us other gods, neither incense, nor laurels, nor cakes, nor victims, nor anything in the world.

In none of these cases does the negative ov negate the predicative verb, and consequently, nowhere does it function as sentential negation. It might suggest some sort of

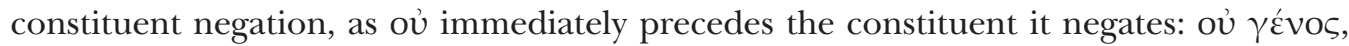

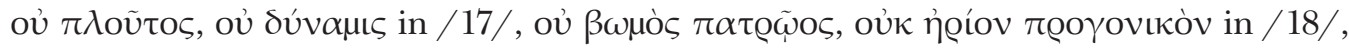

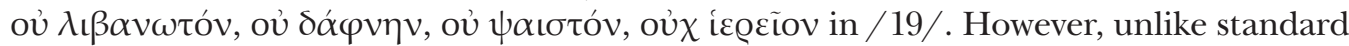
cases of constituent negation implying that an action itself has been accomplished, ${ }^{33}$ the Greek examples make it obvious that the actions concerned have not been or will not be accomplished (e.g. in $/ 17 /$, there will not be wealth). This, though, is not determined by the negator ov่, but rather by the presence of sentential negation, in this case represented by corresponding forms of the n-word oúdís. Consequently, the n-word functions as negation operator (similarly as in the cases where a sentence has no negator, such as $/ 11 /$ ), having under its scope the finite verb, whereas ov negates asyndetically linked noun phrases,${ }^{34}$ which can be described as local negations. ${ }^{35}$ Therefore, the above examples do not involve double negation (affirmative reading).

In the fourth example (cf. /20/), nonetheless, oủdeís takes the role of subject, and oú negates the predicate; consequently, there is a close syntactical relationship between both negatives, like in $/ 15 /$ and / $16 /$.

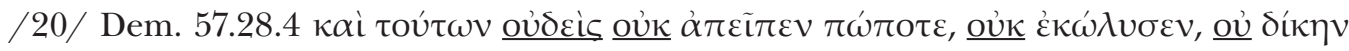

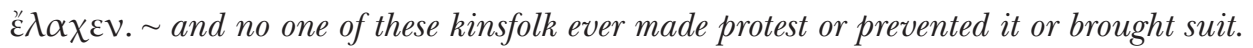

According to the concept of multiple negation presented in Greek grammars, the se-

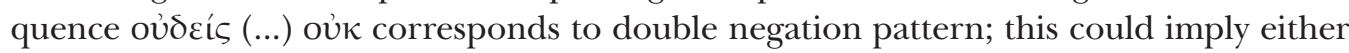
that everyone made protest, or rather that someone made protest. However, considering the context, the translation cannot be other than no one made protest, i.e. with negative concord. Denizot (2012: p. 72 and p. 87) points out that negative reading allows the use of $\pi \omega \tau \sigma \tau \varepsilon$, that is, an indefinite (not negative) adverb which, set in negative context, assumes the meaning of 'never': in modern terminology, it is an NPI (negative polarity item). According to Denizot (2012: n. 16), the negative meaning of the whole sentence is also confirmed by the fact that the verbs have a semantically negative meaning. However, lexically negative items do not make a sentence negative.

\section{The sequence oủdé ... oủ}

33 Cf. Štícha et al. (2013: p. 751): Eva dnes nejela do práce autem (Eva did not go to work by car today) implies that Eva went to work.

34 Example $/ 17 /$ is a case of so-called epexegetic negation, where oúdév is followed by specific nouns negated by means of oủ (oủdév X, oủ $\mathrm{x}_{1}$, oủ $\mathrm{x}_{2}$ ), cf. Denizot (2012: p. 87). For Latin, cf. Pinskster (2015: p. 727).

35 Pinkster (2015: p. 685). 
The last two examples feature the sequence oúdé (...) oủ; the first negative is not a negated indefinite pronoun but a focusing particle. This may account for the absence of double negation. ${ }^{36}$

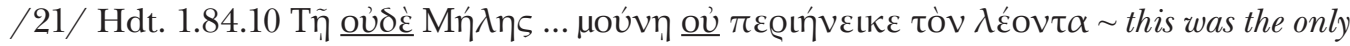
place where Meles ... had not carried the lion.

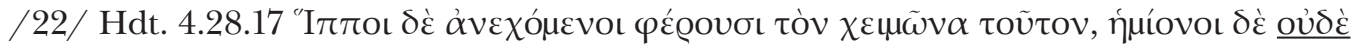

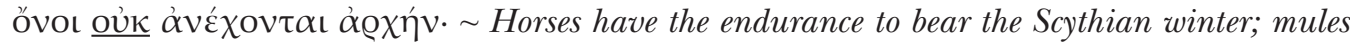
and asses cannot bear it at all. ${ }^{37}$

\subsection{Accumulation of negatives, conclusion}

Let's now recapitulate all cases with the sequence of n-word + negator:

- Grammars usually cite four cases as examples of double negation, though one of them (the fragm. from Sophocles, /13/) should be excluded as spurious because of its varia lectio; another one (Demosthenes, /14/), as Denizot fairly convincingly demonstrated, can be interpreted as an instance of negative concord. This leaves only two cases of double negation, the first of which, from Herodotus $(/ 15 /)$, occurs in a prophecy and involves intentional referential ambiguity; the second one $(/ 16 /)$, from Xenophon, allows the use of an indefinite pronoun with epistemic (referential) value.

- On the other hand, there are six other cases which cannot be interpreted as involving double negation; in three of them $(/ 17 /, / 18 /, / 19 /)$ ov does not negate the finite verb, but a noun constituent; consequently, both negative items operate on different syntactic levels. In two cases the n-word is not a pronoun but the

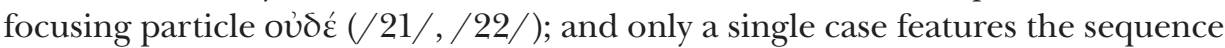
oủdeís ... oủ + verb $(/ 20 /)$.

In my opinion, the scarcity of cases featuring the sequence of n-word + neg rules out the formulation of anything like conclusions. Of course one has to agree with Denizot that the occurrence of two or three cases does not justify the formulation of any rule, let alone its inclusion in school grammar textbooks, all the less so in the presence of counter-examples. Denizot deserves enormous credit for having made this clear and for having analyzed the individual cases in detail. However, I still find it somewhat odd that no commentators or grammarians have yet noticed the peculiarity of this particular construction. For, how could the ancient Greeks read the cases with n-word + negator ov as double negation, if, for them, this construction must actually have represented a rather

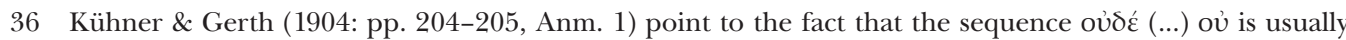
read in terms of negative concord; nonetheless, in the majority of cases they state that the negator ov only follows an interposed subordinate clause, most frequently a concessive clause (oủdé cỉ ... oủ).

37 These examples can also include Demosthenes (cf. / 14/), if we accept Denizot's reading in terms of negative concord. 
agrammatical phenomenon? Denizot (2012: pp. 83-86) explains this contradiction by

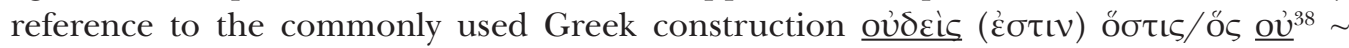
there is no one who (does) not, where, however, the negatives are distributed in two clauses, with the n-word located in the main clause and the negator in the subordinate (relative) clause. ${ }^{39}$ This Greek construction, for which there are parallels in Czech, exemplifies double negation, i.e. its meaning is approximately everyone (yes). ${ }^{40} \mathrm{On}$ the other hand, there

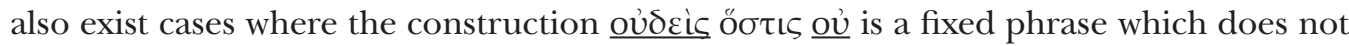
contain a relative clause but rather functions as a kind of complex indefinite expression and is the actual equivalent of $\pi \tilde{\alpha} \varsigma(k a \check{z} d y) .{ }^{41}$ I believe that these fixed phrases may serve as a bridge leading to the explanation of why the n-word + neg construction in a single sentence could perhaps be read in terms of double negation, despite its rare occurrence.

The definition of double negation provided in Greek grammar textbooks is an eloquent example of a case when a vaguely formulated hypothesis (cf. Kühner \& Gerth 1904: p. 205) gains convincingness through gradual assimilation until eventually ending up as a standard rule in school textbooks.

The situation in Ancient Greek is similar to that in non-strict negative concord languages (Italian, Spanish), where there is also no unanimity about whether cases with n-word + negated finite verb should be regarded as ungrammatical, or not. ${ }^{42}$

\section{So-called negative spread}

Another distinctive property of Greek negation is the so-called negative spread, a phenomenon defined by Willis et al. (2013: p. 33) as follows:

\section{/23/ John saw n.thing n.where (negative spread)}

This is a situation where a sentence contains more than one n-word but no negator. Negative concord thus takes place between n-words, ${ }^{43}$ and the resulting reading is negative, which corresponds with the definition of negative concord as presented e.g. by Hor-

38 Cf. Kühner \& Gerth (1904: p. 206, Anm. 6).

39 It is a sort of a negative cleft construction, cf. Pinkster (2015: p. 342, example 1).

40 Whereas the construction with relative clause there is no one who (does) not, which can be interpreted as an instance of double negation, does exist in Czech, the category of double negation, whether in the form of fixed phrase or in a single clause (n-word + neg), does not.

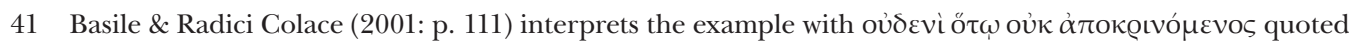
by Denizot (2012: p. 84; Plat. Men. 70c2) as double negation of the same type as in example /15/ here.

42 Penka (2007: p. 269): "A preverbal n-word plus a negative marker is ungrammatical, or at best yields a reading with double negation.” Cf. also Denizot (2012: p. 69, n. 11).

43 Cf. de Swart (2010: p. 46): "The phenomenon whereby the negative concord relation is established exclusively between n-words is called negative spread." 
rocks (cf. section 2) and other scholars whose definitions do not specify whether what is concerned is a negator or an n-word. ${ }^{44}$

Willis et al. regard languages which can feature negative spread, without a negator, as exceptional, citing West Flemish as an example. The same holds true for Ancient Greek. ${ }^{45}$

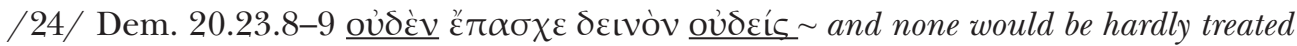

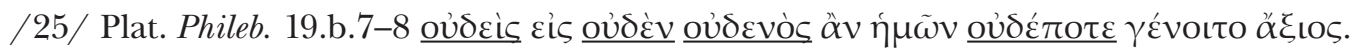
$\sim$ none of us can ever be of any use in anything.

However, according to Willis et al. (2013: p. 33), negative spread can also involve the presence of a negator, in the cases described as co-occurrence of negative spread and negative concord:

/26/ John NEG saw n.thing n.where (negative concord and negative spread)

Languages with a combination of negative concord and negative spread are much more numerous than those with negative spread alone; Willis et al. exemplify this type of language by Lithuanian; nonetheless, as we can see in /27/ and /28/, this phenomenon also occurs in Czech and Ancient Greek:

\section{/27/Jan nikomu nic nedal.}

Jan n-word n-word NEG verb

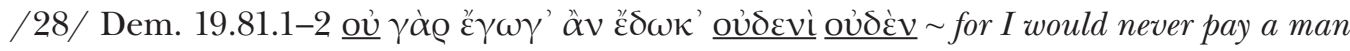
a farthing

Thus, Ancient Greek is a language which features both negative spread alone, and negative spread in combination with a negator, ${ }^{46}$ where negative spread is a specific type of negative concord, namely, that between two (or more) n-words. ${ }^{47}$

44 Also according to Willis et al. (2013: p. 30), negative concord concerns a situation involving "co-occurrence of two or more items (underlined by DM) which would be intuitively judged to be negative".

45 Cf. also example / $12 /$ here.

46 It should be stressed that in Ancient Greek, negative spread in combination with a negator is almost restricted to the neg + n-word + n-word order.

47 Giannakidou (2006: p. 353) also regards negative spread as a specific case of negative concord. However, she only mentions cases where an n-word precedes and another n-word follows the verb; the sentence she quotes does not have a negator, as e.g. the Italian Nessuno ha letto niente. $\sim$ No one has read anything. She does not specify whether the category of negative spread would likewise include cases where both n-words follow the verb, as in my examples $/ 23 /$ and $/ 12 /$, or, on the contrary, all n-words precede it, as e.g. in $/ 25 /$. Negative spread is typical of non-strict negative concord languages. 


\section{Conclusion}

To conclude, characteristic features of negation in Ancient Greek can be summarised as follows:

- the negation operator which usually functions as sentential negation is the negator oú;

- in absence of the negator its role is assumed by an n-word (that precedes or follows the verb). In other words, sentence negation is achieved either by the negator, or - in its absence - by an n-word (cf. /11/ and / 12/), similarly as in Italian, Spanish, but also in English;

- a sentence may contain more than one n-word, in both preverbal and postverbal positions (cf. /24/ and /25/), i.e. Greek features the phenomenon known as negative spread, which entails negative concord between n-words;

- however, a sentence can contains not only several n-words, but also the negator. In such cases, Ancient Greek allows (albeit rather rarely) the co-occurrence of negative concord and negative spread (cf. /28/);

- relative ordering of neg + n-word must be taken into consideration:

$\circ$ the sequence neg $+n$-word signals negative concord;

○ the squence n-word + neg, which is very rare, ${ }^{48}$ may entail interpretation in terms of both negative concord and double negation. As was shown, there are similarly equivocal cases in Spanish and Italian;

- given the scarcity of examples, I claim that the sequence n-word + neg could perhaps be perceived - in antiquity - as peculiar // agrammatical, and therefore avoided. Similarly, Italian and Spanish speakers do avoid the same construction nowadays.

- Ancient Greek should be regarded as a non-strict negative concord language as well as Italian and Spanish.

It is obvious that Ancient Greek cannot be regarded as either a non-negative concord language, as is stated by Giannakidou, ${ }^{49}$ or a strict negative concord language, as is claimed, without detailed discussion, by Denizot. ${ }^{50}$ The present analysis shows that Ancient Greek - unlike Modern Greek - is a non-strict negative concord language, ${ }^{51}$ even though it may differ in some points from prototypical non-strict negative concord languages. After all, given the continuous, non-discrete nature of linguistic categories, differences between types of negation in individual languages need not always be strictly delineated. On the other hand, it is important to take into consideration the fact that approaches to modern languages applied to Ancient Greek ought to be carefully veri-

48 My analysis of Denizot's examples has revealed that no more than three relevant examples are available: two with double negation reading and one with negative concord, not counting cases with a complex indefinite.

49 Giannakidou (2006: p. 364): "The absence of NC [negative concord, DM] in ancient Greek is parallel to the absence of NC in English..."

50 Denizot (2012: p. 68): “... langue à concordance négative généralisée.”

51 Similar views have been submitted by Horrocks (2014) and Willmott (2013). 
fied, with thoroughgoing consideration of potential consequences. It should for instance be borne in mind that in contrast to modern linguistic concepts, scholarly grammars of Ancient Greek do not work with negative indefinites but rather with compound nega-

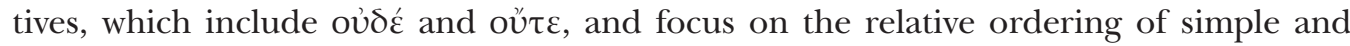
compound negatives rather than on the position of n-words with respect to the verbs.

\section{Bibliography}

Basile, N., \& Radici Colace, P. (2001). Sintassi storica del greco antico (2. ed.). Bari: Levante editori. Bornemann, E., \& Risch, E. (1978). Griechische Grammatik (2. ed.). Frankfurt am Main: M. Diesterweg.

Crespo, E. et al. (2003). Sintaxis del griego clásico (especially pp. 222-225). Madrid: Gredos.

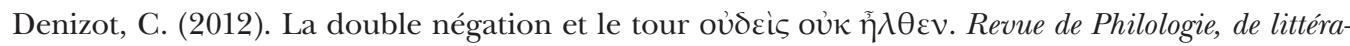
ture et d'histoire anciennes, 86(2), 65-90.

Dočekal, M. (2007). Autonomie syntaxe: negace a NPI [Autonomy of syntax: negation and NPI]. Linguistica online. [Accessed on 31. 8. 2016 from

http://www.phil.muni.cz/linguistica/art/docekal/doc-001.pdf].

Dočekal, M. (2015). Czech Negation from the Formal Perspective. München: Lincom.

Giannakidou, A. (2006). N-words and negative concord. In M. Everaert et al. (Eds.), The Blackwell companion to Syntax (Vol. III; Chap. 45, pp. 327-391). Oxford: Wiley-Blackwell.

Giannakidou, A. (2011). Negative and positive polarity items. In C. Maienborn, K. von Heusinger, \& P. Portner (Eds.), Semantics: An International Handbook of Natural Language Meaning (Vol. II, pp. 1660-1712). Berlin: De Gruyter.

Hajičová, E. (1975). Negace a presupozice ve významové stavbě věty [Negation and presupposition in the semantics of sentence structure]. Praha: Academia.

Haspelmath, M. (2013). Negative Indefinite Pronouns and Predicate Negation. In M. S. Dryer, \& M. Haspelmath (Eds.), The World Atlas of Language Structures Online (= WALS; chapter 115). Munich: Max Planck Institute for Evolutionary Anthropology. [Available online: http://wals.info/ chapter/115; Accessed on 31.8.2016].

Horrocks, G. (2014). Ouk Ísmen Oudén: Negative Concord and Negative Polarity in the History of Greek. Journal of Greek Linguistics, 14, 43-83.

Humbert, J. (1972). Syntaxe grecque. Paris: Klincksieck.

Kosta, P. (2001). Negace a větná struktura v češtině [Negation and sentence structure in Czech]. Čeština - univerzália a specifika, 3, 117-138.

Kühner, R., \& Gerth, B. (1904). Ausführliche Grammatik der griechischen Sprache. (Vol. II, 2; pp. 178-223). Hannover-Leipzig: Hahnsche Buchhandlung.

Mluvnice češtiny [Czech Grammar] = Petr, J. et al. (1987). Akademická mluvnice čěstiny, III: Skladba [Academic Grammar of Czech Language - Syntax] (especially pp. 260-278). Praha: Academia.

Muchnová, D. (2014). „Negation“ and „Negation (morphology)“. In G. Giannakis et al. (Eds.), Encyclopedia of Ancient Greek Language and Linguistics (pp. 484-491 and 491-492). Leiden: Brill. Niederle, J. et al. (1974). Mluvnice řeckého jazyka [Greek Language Grammar]. Praha: SPN.

Penka, D. (2007). A crosslinguistic perspective on n-words. ASJU (Anuario del Seminario de Filología 
Vasca "Julio de Urquijo"), XLI(2), 267-283. [Retrieved 31. 8. 2016 from http://www.ehu.eus/ojs/ index.php/ASJU/article/viewFile/3904/3518].

Pinkster, H. (2015). The Oxford Latin Syntax. (Vol. I: The simple clause). Oxford: OUP.

Radt, S. (Ed.). (1977). Tragicorum Graecorum fragmenta (Vol. 4). Göttingen: Vandenhoeck \& Ruprecht.

Rijksbaron, A. et al. (2000). Beknopte syntaxis van het klassiek Grieks. Lunteren: Hermaion.

Schwyzer, E., \& Debrunner, A. (1950). Griechische Grammatik, II: Syntax und syntaktische Stilistik (especially pp. 590-599). Munich: C. H. Beck.

Smyth, H. W. (1984). Greek grammar (revised by G. M. Messing; especially pp. 608-630). Harvard: University Press.

Swart, H. de (2010). Expression and Interpretation of Negation: An OT Typology. Dordrecht-Heidelberg: Springer.

Štícha, F. et al. (2013). Akademická gramatika spisouné češtiny [Academic Grammar of Standard Czech]. Praha: Academia.

Willis, D. et al. (2013). Indefinites: Basic Concepts. In D. Willis et al. (Eds.), The History of Negation in the Languages of Europe and the Mediterranean (Vol. I; pp. 27-35). Oxford: Oxford University Press.

Willmott, J. (2013). Negation in the history of Greek. In D. Willis et al. (Eds.), The History of negation in the languages of Europe and the Mediterranean (Vol. I; pp. 299-340). Oxford: Oxford University Press.

Doc. PhDr. Dagmar Muchnová, CSc. / Dagmar.Muchnova@ff.cuni.cz

Institute of Greek and Latin Studies

Charles University, Faculty of Arts

Nám. Jana Palacha 2, 11638 Praha, Czech Republic 